\title{
Effects of storage methods and duration on the microbial composition and load of tomato (Solanum lycopersicum [L.], Solanaceae) fruits
}

\author{
aDepartment of Plant Biology and Biotechnology, Faculty of Life Sciences, University of Benin, Benin City, Nigeria \\ ${ }^{b}$ School of Biological Sciences, College of Natural Sciences, Seoul National University, Seoul 08826, Korea Rep.
}

Matthew Chidozie Ogwu $u^{a, b},{ }^{*}$, Anthonia Odinita Chime ${ }^{a}$, Raymond Osas Aiwansobaa, Alvin O. Emere ${ }^{a}$

\section{A R T I C LE IN F O}

\section{Article history:}

Received 12 January 2018

Received in revised form 02 February 2019

Accepted 19 June 2019

\section{Keywords:}

Tomato (Solanum lycopersicum)

Fruit storage

Microbial load

Economic plants

Fruitosphere

\begin{abstract}
A B S T R A C T
Tomato is a widely cultivated fruit vegetable in Nigeria. They are valued for their fruits, which are consumed fresh or processed. The method and duration of storage have profound effects on the economic value and utilization of the fruits. Therefore, this study was set up to investigate the efficacy of three common storage methods (plastic basket, concrete floor and refrigeration at $4{ }^{\circ} \mathrm{C}$ ) by conducting microbial assessment. Freshly harvested fruits were sourced from two locations in Benin City, Nigeria and stored for a period of four weeks. Microbial composition and load was determined using standard laboratory techniques initially (on the first day) and every week afterwards. Results showed that the microbial load increased with prolonged storage. Tomato fruits stored in plastic basket had the highest mean total microbial count $\left(132 \times 10^{5} \mathrm{CFU} / \mathrm{mL}\right)$, whereas those stored in the refrigerator had the least $\left(3 \times 10^{5}\right.$ $\mathrm{CFU} / \mathrm{mL}$ ). The common microorganisms isolated from the stored fruits include the fungi; Aspergillus niger, A. flavus, Rhizopus, Penicillium spp., and yeast cells as well as the bacteria; Staphylococcus sp. E. coli, Salmonella and Enterobacter spp. These results suggest that refrigeration will extend the shelf life of tomato fruits and minimize the rate of spoilage due to microbial composition and load.
\end{abstract}

\section{Introduction}

Tomato is a member of the nightshade family (Solanaceae), which most likely originated from South America in the Andes Mountains where wild varieties can still be found in the coastal mountains of Ecuador Peru and Northern Chile (Chime et al., 2017a). Hillock (2011) inferred from herbal books that the pre-Mayan people of Central America first domesticated it. It has since spread beyond the Americas and cultivated in diverse environmental conditions and climes with specific cultural practices evolving overtime (Chime et al., 2017b). The fruits are the most preferred part, which is used as food either fresh or in various processed forms because of their phytochemical composition (Simonne et al., 2006; Toor and Savage, 2006; Naseer et al., 2012; Murali et al., 2013).

In Nigeria, tomato is cultivated virtually across the country but most significantly grown in places like Zaria, Jos, Gombe, Kano,
Maiduguri, Ogbomosho and Ibadan (McGriffen et al., 1994). The crop is sensitive to frost and grows well under average monthly temperature of $21-23{ }^{\circ} \mathrm{C}$. It requires moisture of about $60 \mathrm{~mm}$ and well-drained light loam soils with high organic matter content and $\mathrm{pH}$ of $5-7.5$. The crop is mainly cultivated by seeds and needs careful logging alongside necessary cultural practices to improve growth and yield. Although tomato productivity depends on the potential of the genotype used and availability of resources. Low and declining soil fertility is a major concern in many African smallholder farms, which has been exacerbated by continuous cultivation without adequate soil fertility enhancement measures. Inorganic fertilizers can improve crop yields but its use is limited due to scarcity, high cost, nutrient imbalance and soil acidity (Mbah, 2006).

More so, transportation and storage are the major overriding constraint that affects vegetable (tomato) availability in Nigeria and Africa (Ogwu et al., 2016a). Currently, crude and 
non-sophisticated methods are applied for storage and transportation of tomato, which have led to large-scale fruit spoilage and overshadows productivity. The resulting mechanical injuries (i.e. cuts and punctures) leads to fruit decay and reduces the economic value of the crop (Chiejina and Ukeh, 2012). The succulent nature of the fruit requires peculiar storage conditions to prevent microbial infection. Diseases are a major limiting factor for tomato production and availability and could be contagious, hence, may spread from plant to plant, often very rapidly when environmental conditions are favourable (Damicone and Lynn, 2013). Understanding the required storage conditions may help prevent the proliferation of diseases. Unlike phyllosphere, the fruitosphere is yet to attract much attention yet it is critical. The fruitosphere (also called the carposphere), may be defined as the narrow region immediately around the fruit exocarp, which may contain secretions from the fruit as well as certain class of microorganisms.

Several works have been undertaken with a view to determine the effects of pre and post-harvest treatments such as chemical, packaging and atmosphere control on the storage and microbial characterization of fresh fruits and vegetables (Salunkhe and Norton, 1960; Singh 1970; Kader, 1983; Artes et al., 2006; Tahir et al., 2009; Ogwu et al., 2016b; Chime et al., 2016). These works have outlined the specific conditions for fruit storage as well as the chemical and physical changes but with few focus on tomato and increasing importance of the crop, there is need for more investigation. Therefore, this study aims to investigate the effects of various storage methods and duration on the microbial composition and load of tomato fruit. The bacteria and fungi composition of the fruits will be documented at different stages during storage for each of the method adopted in the study. More so, the suitability of the fruits for consumption will be observed and evaluated firmness of the fruits and oozing odour. This may be a direct consequence of the microbial load at that point in storage. Through this study, the suitability of each storage method may be inferred as well as the effects on the shelf life of freshly harvested tomato fruits.

\section{Materials and Methods}

\subsection{Collection of tomato fruits}

Fresh tomato fruits were collected from the newly harvested stock of two local farmers in Benin City (Ikpoba Okha and Egor), Southern Nigeria. The tomato fruits are cultivated varieties, which have been maintained by the farmers for generations. Seeds of previous harvest are often kept until the next growing season and reused. The cultivars represent a large proportion of the tomato sold in major markets in the metropolis. At the time of collection, the fruits were characteristically red in colour, oblong in shape; fresh, ripened, undamaged and firm (Plate 1A).

\subsection{Methods of storage}

Three storage methods were adopted in the study including standard refrigeration at $4{ }^{\circ} \mathrm{C}$ (Plate $\left.1 \mathrm{~B}\right)$, in a plastic basket (Plate 1C) and on a clean concrete floor (Plate 1D). The refrigeration temperature of fruits depends on the region (centre of origin) and source of the fruits. Therefore, the refrigeration condition adopted was inferred from Renard et al. (2013). The refrigeration was done using Haier Thermocool (HRF-160EX). Storage of fruits in plastic basket is widely practised in urban and sub-urban Nigeria whereas storage of fruits on concrete floors is mainly practised in rural centres but also in city centres. The fresh fruits where stored in open blue coloured plastic basket as well as on the concrete floor at room temperature. The tomato fruits were maintained under the different storage conditions for four weeks. They were taken out briefly (for 20 mins) to make observations and to collect samples for microbial assessment (composition and load analysis) at an interval of seven days. An initial microbial assessment was conducted prior to storage (day 1).
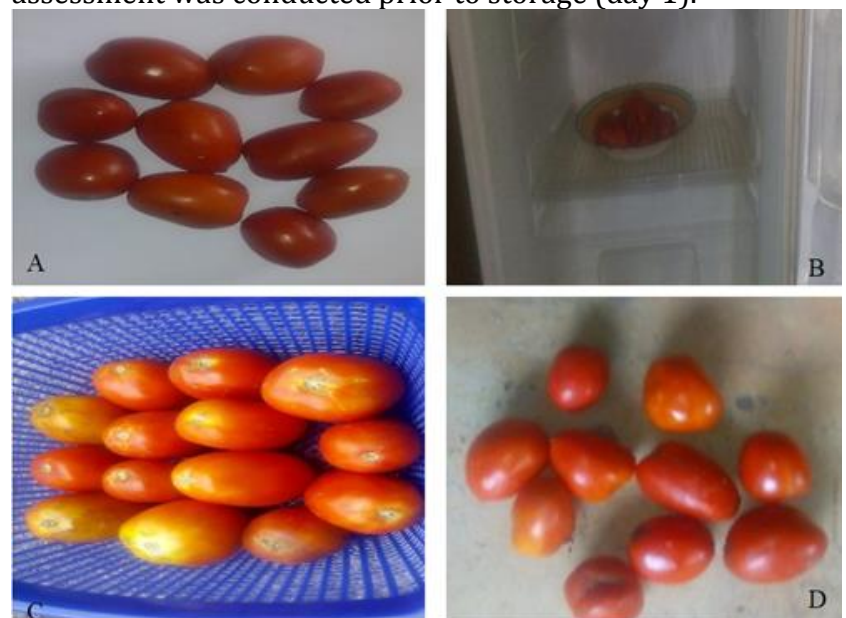

Figure 1: Freshly harvested fruits of Tomato (S. lycopersicum Linn) [A], different methods of storage evaluated in the study; [B] refrigerator at $4{ }^{\circ} \mathrm{C}[\mathrm{C}]$ basket and [D] concrete floor at room temperature

\subsection{Isolation and Characterization of Bacteria and Fungi}

The isolation and characterization of bacteria and fungi on the stored tomato fruits were performed according to adapted methods previously outlined in Osawaru et al., (2013), Ogwu and Osawaru (2014), Ogwu and Osawaru (2015) and herein summarized. Three fruits were selected and removed from storage category. From each fruit, a portion is excised and placed in a $10 \mathrm{ml}$ sterile distilled water and hand shaken for 20 minutes. A quantity $(1 \mathrm{ml})$ of the stock suspension was diluted into $9.0 \mathrm{ml}$ of diluent for up to five times $\left(10^{-1}, 10^{-2}, 10^{-3}, 10^{-4}\right.$ and $10^{-5}$ ) for uniform distribution of the cells (conidia). One millilitre of the aliquots from $10^{-1}$ and $10^{-5}$ dilutions of each were transferred to sterile Petri plates with three replicates for each dilution for bacteria and fungi isolates. Cheek cool molten agar (Nutrient agar) for bacteria and Potato Dextrose Agar (PDA) for fungi were poured into Petri dishes (pour plate method). Plates were incubated at room temperature $(28 \pm 2$ o C) for 24 hours (for bacterial isolates) in inverted position and 3 - 5 days for fungal isolates under fluorescent daylight. Colony forming units per millilitres (CFU/mL) were counted as described by Codina et al., (2008); Mukhtar et al., (2010) and (2012).

Microbial isolates were identified and characterized using standard microbiological techniques. Fungal isolates were Identified using nonculturable or culturable analysis as a surrogate measure of exposure to fungi and the spores identified at the genus level or classified into groups following general taxonomic guidelines currently accepted by the scientific community (Codina et al., 2008). Fungal colonies 
were counted after 3 - 5 days. Each fungal colony was purified and identified on the basis of morphological characteristics to meet relevant taxonomic requirements. Characteristics features of bacterial strains/colonies were also identified based upon standard physiological, biochemical and morphological characteristics. Isolated fungi were characterized by macroscopic (physical appearance on agar plates) and microscopic techniques (under light microscope) including colour of aerial and substrate mycelia. Thus, comparing them with those of known taxa as described by (Domsch and Gams, 1970). Each isolates were done as described by Cowan (1974), Holt et al. (1994). The basic identification keys used included Domsh et al. (1993) and Barnett and Hunter (1998) using morphological and microscopic characteristics. Frequency of individual microbial species was calculated in percentage as follows;

Microbial frequency $(\%)=$ number of colony of the species appeared $\times 100 /$ Total number of all colony isolated from each sample.

\section{Results}

The results of the total microbial count on the tomatoes fruits stored under different conditions are presented in Table 1 to 4 . Results revealed that the total microbial count of the tomatoes fruits vary from $3 \times 10^{5}$ to TNC (count greater than 300 ). The counts varied for each of the storage method and initial count obtained from fresh (not stored) sample. The count value obtained from Ikpoba Okha fruits on potato dextrose agar had least count under refrigeration. The fungi associated with the tomato fruits from Ikpoba Okha and Egor under the different storage conditions include A.niger, A. flavus, Rhizopus, Penicillium spp., and yeast cells while the bacteria isolates includes Staphylococcus spp., E. coli, Salmonella and Enterobacter spp. (Tables 5 - 8)

Table 1: Mean total viable microbial count (CFU/mL) of tomato fruits from Ikpoka Okha on potato dextrose agar

\begin{tabular}{lcccc}
\hline \multicolumn{5}{c}{ Microbial count (CFU/mL) x 105 } \\
Storage time & Fresh sample & Basket & Floor & Fridge \\
\hline Day 1 & 72 & - & - & - \\
1 week & - & TNC & 80 & 3 \\
2 weeks & - & 67 & 77 & 97 \\
3 weeks & - & 7 & 40 & 17 \\
4 weeks & - & 18 & 58 & 3 \\
\hline
\end{tabular}

$\mathrm{TNC}=$ count greater than 300

Table 2: Mean total viable microbial count ( $\mathrm{CFU} / \mathrm{mL})$ of tomato fruits from Ikpoba Okha on nutrient agar

\begin{tabular}{lllll}
\hline & \multicolumn{5}{c}{ Microbial count $(\mathbf{C F U} / \mathbf{m L}) \times \mathbf{1 0}^{\mathbf{5}}$} \\
Storage time & Fresh sample & Basket & Floor & Fridge \\
\hline Day 1 & TNC & - & - & - \\
1 week & - & 3422 & 44 & \\
2 weeks & - & 132 & 47 & 23 \\
3 weeks & - & TNC & TNC & TNC \\
4 weeks & - & 2352 & 49 & \\
\hline
\end{tabular}

$\mathrm{TNC}=$ count greater than 300
Table 3: Mean total viable microbial count $(\mathrm{CFU} / \mathrm{mL})$ of tomato fruits from Egor on potato dextrose agar

\begin{tabular}{llcccc}
\hline & \multicolumn{5}{c}{ Microbial count $(\mathrm{CFU} / \mathbf{m L}) \times \mathbf{1 0}^{\mathbf{5}}$} \\
Storage time & Fresh sample & Basket & Floor & Fridge \\
\hline Day 1 & 72 & - & - & - \\
1 week & - & TNC & 80 & - \\
2 weeks & - & 30 & TNC & - \\
3 weeks & - & 7 & 40 & 97 \\
4 weeks & - & 17 & 40 & \\
\hline
\end{tabular}

$\mathrm{TNC}=$ count greater than 300

Table 4: Mean total viable microbial count (CFU/mL) of tomato fruits from Egor on nutrient agar

\begin{tabular}{lllll}
\hline & \multicolumn{4}{c}{ Microbial count $(\mathrm{CFU} / \mathbf{m L}) \times \mathbf{1 0}^{5}$} \\
Storage time & Fresh sample & Basket & Floor & Fridge \\
\hline Day 1 & TNC & - & - & - \\
1 week & - & - & - & - \\
2 weeks & - & 40 & 144 & 62 \\
3 weeks & - & TNC & TNC & TNC \\
4 weeks & - & 21 & 52 & 13 \\
\hline
\end{tabular}

TNC= count greater than 300
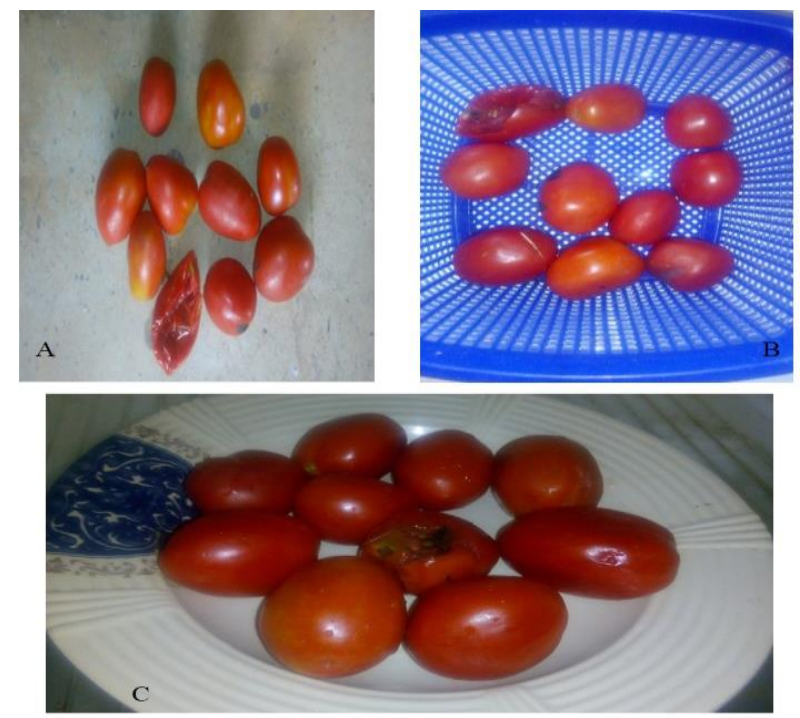

Figure 2: Tomato fruits after one week; $\mathrm{A}=$ floor, $\mathrm{B}=$ basket, $\mathrm{C}$ = fridge
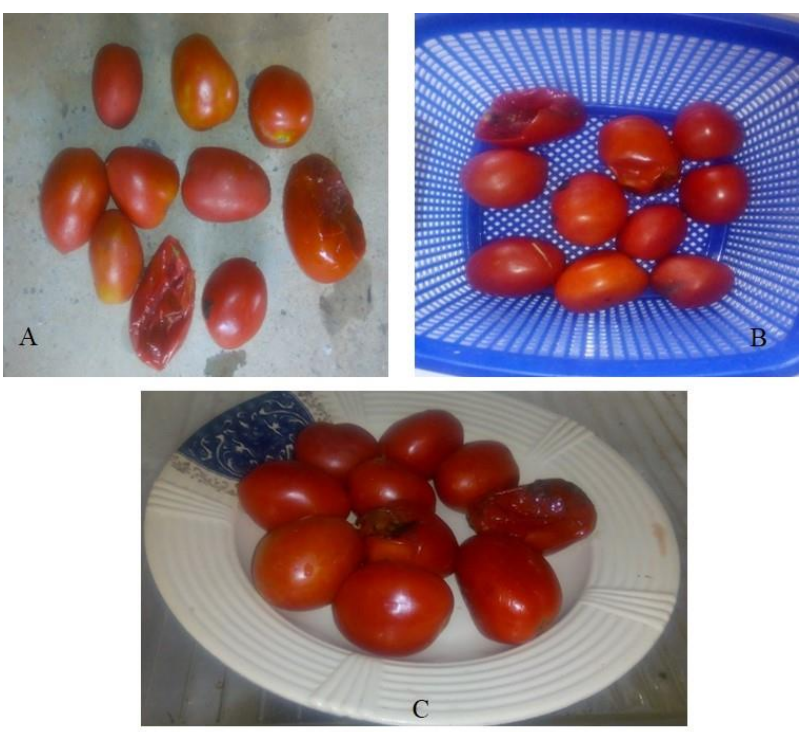

Figure 3: Tomato fruits after two week; $A$ = basket, $B$ = floor, $C$ = fridge 

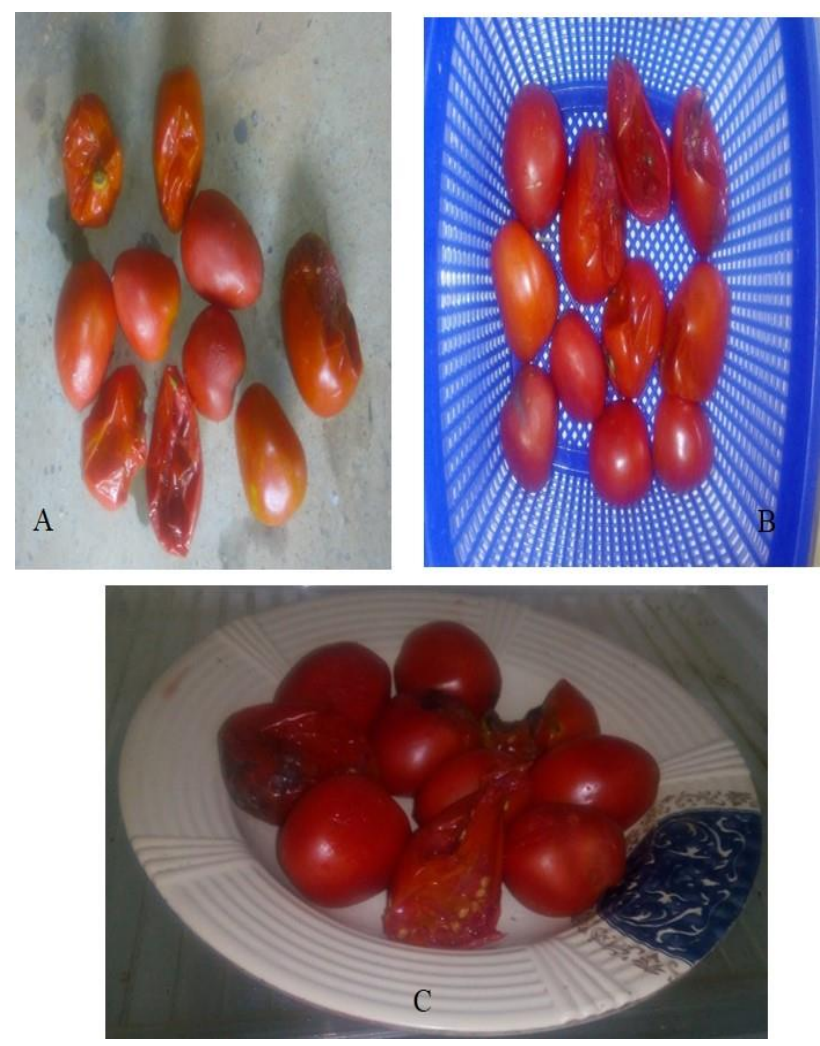

Figure 4: Tomato fruits after four weeks; $\mathrm{A}=$ floor, $\mathrm{B}=$ basket, $\mathrm{C}=$ fridge

Table 5: Microbial characterization of isolates from tomato fruits from Ikpoba Okha and stored under different conditions

\begin{tabular}{|c|c|c|c|c|}
\hline \multirow[b]{2}{*}{ Period } & \multicolumn{4}{|c|}{ Storage methods } \\
\hline & Fresh & Basket & Fridge & Floor \\
\hline Day 1 & $\begin{array}{l}\text { Aspergill } \\
\text { us niger } \\
\text { Staphylo } \\
\text { coccus } \\
\text { aureus }\end{array}$ & - & - & - \\
\hline 1 week & & $\begin{array}{l}\text { Aspergill } \\
\text { us niger } \\
\text { Penicilliu } \\
m \\
\text { notatum }\end{array}$ & $\begin{array}{l}\text { Staphylococc } \\
\text { us aureus }\end{array}$ & $\begin{array}{l}\text { Aspergillus } \\
\text { niger }\end{array}$ \\
\hline 2 weeks & & $\begin{array}{l}\text { Rhizopus } \\
\text { species }\end{array}$ & $\begin{array}{l}\text { Rhizopus } \\
\text { species }\end{array}$ & $\begin{array}{l}\text { Staphylococc } \\
\text { us species }\end{array}$ \\
\hline 3 weeks & & $\begin{array}{l}\text { Aspergill } \\
\text { us niger } \\
\text { Penicilliu } \\
m \\
\text { notatum }\end{array}$ & Yeast cells & $\begin{array}{l}\text { Salmonella } \\
\text { species } \\
\text { Escherichia } \\
\text { coli }\end{array}$ \\
\hline & & $\begin{array}{l}\text { Salmonel } \\
\text { la species }\end{array}$ & & $\begin{array}{l}\text { Salmonella } \\
\text { species }\end{array}$ \\
\hline 4 weeks & & $\begin{array}{l}\text { Aspergill } \\
\text { us flavus }\end{array}$ & $\begin{array}{l}\text { Staphylococc } \\
\text { us aureus }\end{array}$ & Yeast cells \\
\hline & & $\begin{array}{l}\text { Rhizopus } \\
\text { species }\end{array}$ & $\begin{array}{l}\text { Staphylococc } \\
\text { us aureus }\end{array}$ & $\begin{array}{l}\text { Staphylococc } \\
\text { us aureus }\end{array}$ \\
\hline
\end{tabular}

Table 6: Microbial characterization of isolates on tomato fruits from Egor stored under different conditions

\begin{tabular}{|c|c|c|c|c|}
\hline \multirow[b]{2}{*}{ Period } & \multicolumn{4}{|c|}{ Storage method } \\
\hline & Fresh & Basket & Fridge & Floor \\
\hline \multirow[t]{6}{*}{ Day 1} & Aspergillus & - & - & - \\
\hline & niger & & & \\
\hline & Penicillium & & & \\
\hline & notatum & & & \\
\hline & Staphyloco & & & \\
\hline & ccus aureus & & & \\
\hline \multirow[t]{8}{*}{1 week } & & Aspergill & Salmonella & \\
\hline & & Penicilliu & Enterobacte & Enterobacte \\
\hline & & & $r$ species & $r$ species \\
\hline & & notatum & & \\
\hline & & Aspergill & Staphylococ & Yeast cells \\
\hline & & us flavus & cus aureus & \\
\hline & & Rhizopus & Staphylococ & Staphylococ \\
\hline & & species & cus aureus & cus aureus \\
\hline \multirow[t]{4}{*}{2 weeks } & & Aspergill & Escherichia & Staphylococ \\
\hline & & us flavus & coli & cus aureus \\
\hline & & Rhizopus & Samonella & Samonella \\
\hline & & species & species & species \\
\hline \multirow[t]{5}{*}{3 weeks } & & Aspergill & Samonella & Aspergillus \\
\hline & & us niger & species & niger \\
\hline & & Penicilliu & Escherichia & Staphylococ \\
\hline & & $m$ & coli & cus species \\
\hline & & notatum & & \\
\hline \multirow[t]{4}{*}{4 weeks } & & $\begin{array}{l}\text { Yeast } \\
\text { cells }\end{array}$ & Yeast cells & Yeast cells \\
\hline & & Staphylo & & Staphylococ \\
\hline & & coccus & & cus aureus \\
\hline & & aureus & & \\
\hline
\end{tabular}

Table 7: Characterization and identification of bacteria on tomato fruits from Ikpoba Okha and Egor

\begin{tabular}{|c|c|c|c|c|c|}
\hline Isolates & $\begin{array}{l}\text { Colon } \\
\text { y } \\
\text { Shape }\end{array}$ & $\begin{array}{l}\text { Colon } \\
\text { y } \\
\text { colou } \\
\text { r }\end{array}$ & $\begin{array}{l}\text { Margi } \\
n \quad \text { of } \\
\text { Colon } \\
y\end{array}$ & $\begin{array}{l}\text { Cell type } \\
\text { and } \\
\text { Arrangeme } \\
\text { nt }\end{array}$ & $\begin{array}{l}\text { Gra } \\
\text { m } \\
\text { stai } \\
\text { n }\end{array}$ \\
\hline $\begin{array}{l}\text { Salmonella } \\
\text { species }\end{array}$ & $\begin{array}{l}\text { Circul } \\
\text { ar }\end{array}$ & $\begin{array}{l}\text { Crea } \\
\mathrm{m}\end{array}$ & Entire & $\begin{array}{l}\text { Rod shape } \\
\text { in clusters }\end{array}$ & - \\
\hline $\begin{array}{l}\text { Escherichia } \\
\text { coli }\end{array}$ & $\begin{array}{l}\text { Circul } \\
\text { ar }\end{array}$ & $\begin{array}{l}\text { Crea } \\
\mathrm{m}\end{array}$ & Entire & $\begin{array}{l}\text { Rod shape } \\
\text { in clusters }\end{array}$ & - \\
\hline $\begin{array}{l}\text { Staphylococc } \\
\text { us aureus }\end{array}$ & $\begin{array}{l}\text { Circul } \\
\text { ar }\end{array}$ & $\begin{array}{l}\text { Crea } \\
\mathrm{m}\end{array}$ & Entire & $\begin{array}{l}\text { Cocci cells in } \\
\text { chains }\end{array}$ & - \\
\hline $\begin{array}{l}\text { Enterobacter } \\
\text { species }\end{array}$ & $\begin{array}{l}\text { Circul } \\
\text { ar }\end{array}$ & $\begin{array}{l}\text { Crea } \\
\mathrm{m}\end{array}$ & Entire & $\begin{array}{l}\text { Rod shape } \\
\text { in clusters }\end{array}$ & - \\
\hline
\end{tabular}


Table 8: Characterization and identification of fungi on tomato fruits from Ikpoba Okha and Egor

\begin{tabular}{|c|c|c|c|c|}
\hline Isolates & $\begin{array}{l}\text { Textur } \\
\text { e of } \\
\text { Conidia }\end{array}$ & $\begin{array}{l}\text { Conidi } \\
\text { a shape }\end{array}$ & $\begin{array}{l}\text { Presence of } \\
\text { Pseudohypha } \\
\text { e }\end{array}$ & $\begin{array}{l}\text { Colony } \\
\text { shape }\end{array}$ \\
\hline $\begin{array}{l}\text { Aspergillus } \\
\text { notatum }\end{array}$ & $\begin{array}{l}\text { Slightly } \\
\text { rough }\end{array}$ & $\begin{array}{l}\text { Globula } \\
\mathrm{r}\end{array}$ & Presence & Globular \\
\hline $\begin{array}{l}\text { Aspergillus } \\
\text { flavus }\end{array}$ & $\begin{array}{l}\text { Slightly } \\
\text { rough }\end{array}$ & $\begin{array}{l}\text { Ellipsoi } \\
\text { d }\end{array}$ & Presence & $\begin{array}{l}\text { Granula } \\
\mathrm{r}\end{array}$ \\
\hline $\begin{array}{l}\text { Penicillium } \\
\text { notatum }\end{array}$ & $\begin{array}{l}\text { Powder } \\
\mathrm{y}\end{array}$ & Round & Absence & Globular \\
\hline $\begin{array}{l}\text { Rhizopus } \\
\text { species }\end{array}$ & Wooly & $\begin{array}{l}\text { Lemon } \\
\text { shaped }\end{array}$ & Presence & $\begin{array}{l}\text { Spherica } \\
\text { l }\end{array}$ \\
\hline $\begin{array}{l}\text { Saccharomyc } \\
\text { es cerevisiae } \\
\text { (Yeast) }\end{array}$ & $\begin{array}{l}\text { Slightly } \\
\text { rough }\end{array}$ & Oval & Presence & Oval \\
\hline
\end{tabular}

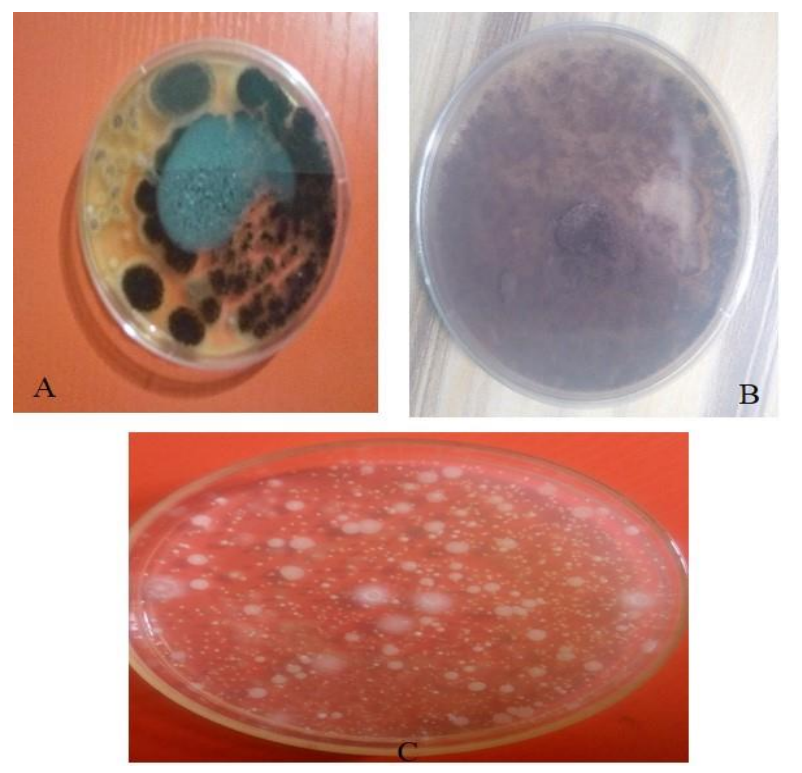

Figure 5: Some microorganism isolated; $\mathrm{A}=$ Aspergillus niger, $\mathrm{B}=$ Aspergillus flavus, $\mathrm{C}=$ Saccharomyces cerevisiae (Yeast)

\section{Discussion}

The microorganisms associated with stored tomato have been investigated. These fruitospheric organisms may be responsible for the storage condition of the fruit at any given point under storage. Although fresh fruity-vegetable such as tomato have their natural protective epidermal layer that effectively guide against most pathogenic microbes and plant spoilage (Bello et al., 2016). The nature of the exocarp as well as the range of antagonistic microorganisms, which will vary from one plant to another, may cause this protection. Yet as determined by this study, this natural protection is not enough to shield tomato fruits obtained locally within the Benin metropolis. As reported by Onuorah and Orji (2015), the large water content in tomato fruit makes it highly susceptible to spoilage by microorganisms such as fungi, which may produce mycotoxins with public health risks. Therefore, the inherent protection is affected, thus, the fruits may become contaminated under storage. However, this contamination may have occurred before the fruits are held in storage for instance, during field cultivation, harvesting, postharvest handling and distribution (Beuchat, 2002). Endophytic bacterial communities on tomato leaves could exert multiple effects on growth and health of tomato plants, which may ultimately affect the fruit and fruit quality (Romero et al., 2014). This report by Romero implicate the possibility of phyllospheric microorganisms to cross-contaminate the fruits during development. Especially if fruits were accidentally wounded during transportation. This may cause rapidly reproducing spoilage microorganisms to assess open wound sites at the packing or storage facility, and thereby, through shedding from the asymptomatic wound, present the potential for cross-contamination within the facility during handling, culling, washing, sorting, and packing before storage not to affect the facility's sanitation program, that may be difficult to eradicate (Barth et al., 2009). The storage method used in this study contributed to prevent the proliferation of spoilage microorganism at different rates. Refrigerated fruits got spoilt slower than those stored on the floor and basket. The refrigeration temperature may be responsible because of the nature of the fruit. Contrary to what was anticipated the fruits stored on the floor had lower microbial load and stayed fresh longer than those stored in plastic basket.

In a similar study by Wogu and Ofuase (2014), several genera of bacteria and fungi were identified as being associated with the spoilage of tomato fruits. Ghosh (2009) reported fungi to be the major source of spoilage of most of the tomato samples accessed than bacteria. In the present study, the fungi isolated from the different storage conditions of the tomatoes include A. niger, A. flavus, Rhizopus, Penicillium spp., and yeast cells while the bacteria isolates includes Staphylococcus sp, E.coli, Salmonella and Enterobacter spp. These findings is also in line with the work of Chukwu et al. (2008) who had earlier isolated various isolates of bacteria and fungi from tomato fruits. Some of the bacteria isolates isolated by the authors includes Bacillus megaterium and $B$. laterosporus while Chinedu and Enya, (2014); Wogu and Ofuase (2014) found bacteria such as $B$. subtilis, B. cereus, B. aureu, Salmonella typhi, Lactobacillus fermenti, Pseudomonas stutzeri, Leuconostoc spp and Rothia spp, as well as fungi A. flavus, A. fumigatu, Penicillium expansium, Penicillium notatum, Mucor mucido, Rhizopus stolonifer, Botrytis cineria, Saccharomyces sp. and Rhodotorula sp. from tomato fruits. The effect of these microorganism has the potential of causing substantial market losses to both the farmers and traders of tomato fruits across the country. For example, a tomato fruit affected by Rhizopus stolonifer has caused the most rapid rot on stored tomato fruits in Nigeria as observed by Okoli and Erinle (1990).

Fungal spoilage of tomatoes has been recognized as a source of potential health hazard to humans and animals because they produce mycotoxins, which are capable of causing mycotoxicoses in man following ingestion or inhalation (Baker, 2006).

Since tomatoes fruits are sometimes eaten raw, the presences of these microorganisms on tomatoes have been reported to cause human diseases such as meningitis, gastroenteritis, diarrhoea in man following ingestion (Beuchat, 2006). Their major sources of contamination of tomato by microorganism could be because of poor handling practices in the tomato production chain, storage condition, distribution marketing practices and transportation (Beuchat, 1996). The methods used for the storage of the tomatoes samples in this study such 
as storing in basket, keeping on the floor and fridge are those commonly used by man. The results of this study have shown that these methods are inadequate enough for the preservation of tomatoes fruits against microbial infestation.

\section{Conclusion}

This study suggests that the diverse methods used for storing tomato should be revised in line with the results obtained in this study. Future studies is required to confirm our present findings using longer storage period and microbial assessment carried out more than twice a week. Modern sequencing techniques can also be incorporated to credibly obtain the full range of microorganisms associated with each storage method. However, the present unsustainable methods should be discouraged especially in the rural areas, where due to lack of electricity harvested fruits are still stored in baskets and on the floor. Future studies should include sequencing techniques, which make it possible to cover the full range of microorganisms available on the fruitosphere. There should be increased public enlightenment on the potential health hazards associated with the consumption of relatively cheaper ripen-spoilt tomato fruits, as these may be the mediators in foodborne fungal and bacterial diseases. Market wastes and refuse should also be properly disposed of at designated sites to reduce microbial contaminations. Precautionary measures of preservation and handling processes of fruits such as proper sanitary conditions, treatment with antimicrobial agents such as chlorinated water and refrigeration are necessary in reducing microbial composition and load of tomatoes, which are deleterious to human health.

\section{References}

Artes, F., Gomez, P. A. G., Artes-Hernandez, F., 2006. Modified atmosphere packaging of fruits and vegetables. Stewart Postharvest Review, 2(5): 1-13.

Baker, S., 2006. Aspergillus niger genomi cs: past, present and into the future. Medical Mycology, 44(1): S17 - 21.

Barnett, H L., Hunter, B.B., 1998. Illustrated Genera of Imperfect Fungi. Fourth Edition. APS Press, USA. 218p

Barth, M., Hankinson, T.R., Zhuang, H., Breidt, F., 2009. Microbiological Spoilage of Fruits and Vegetables. In: Sperber, W.H., Doyle, M.P. (eds.) Compendium of the Microbiological Spoilage of Foods and Beverages, Food Microbiology and Food Safety. 135-183pp. DOI 10.1007/978-14419-0826-1_6

Bello, O. B., Olawuyi, O. J., Azeez, A. H., Adebisi, O. S., Owoade T. A., 2016. Microorganisms causing postharvest tomato (Solanum lycopersicum L.) fruit decay in Nigeria. Scientia Agriculturae, 13(2): $93-96$.

Beuchat, L. R., 2006. Vectors and conditions for pre-harvest contamination of fruits and vegetables with pathogens capable of causing enteric diseases. Britain food Journal, 108: 38 - 53.

Beuchat, L. R., 1996. Pathogenic organisms associated with fresh produce. Journal of Food Protection, 59: 204 - 216.

Chiejina, N. V., Ukeh, J. A., 2012. Antimicrobial properties and phytochemical analysis of methanolic extracts of Aframomum melegueta and Zingiber officinale on fungal diseases of Tomato fruit. Journal of Natural Sciences Research, 2(6): 2224 - 3186.
Chime, A. O., Aiwansoba, R.O., Danagogo, S. J., Egharevba, I. I., Osawaru, M. E. and Ogwu, M. C., 2016. Effects of linning wih leaves of Triclisia dictyophylla on the fungal composition of Cola nitida during storage. Journal of Industrial Research and Technology, 5(2): 128 - 136

Chime, A.O., Aiwansoba, R.O., Eze, C.J., Osawaru, M.E., Ogwu, M.C., 2017a. Phenotypic characterization of tomato Solanum lycopersicum L.cultivars from Southern Nigeria using morphology. Malaya Journal of Biosciences, 4(1): 31 - 38

Chime, A.O., Aiwansoba, R.O., Osawaru, M.E., Ogwu, M. C., 2017b. Morphological Evaluation of Tomato (Solanum lycopersicum Linn.) Cultivars. Makara Journal of Science, 21(2): 97 -106. doi: 10.7454/mss.v21i2.7421

Chinedu, S. M., Enya, E., 2014. Isolation of Microorganisms associated with deterioration of tomato (Lycopersicon esculentum) and pawpaw (Carica papaya) fruits. International Journal Curricular Microbiology and Applied Science, 3(5): 501 - 512.

Chukwu, E. C, Ogbonna, D. N, Onuegbu, B. A., Adeleke, M. T., 2008. Comparative studies on the fungi and biochemical characteristics of snake guard (Trichosanthes Curcumerina Linn.) and Tomato (Lycopersicon Esculentum Mill.) in Rivers State, Nigeria. Journal of Applied Science, 8(1): 168 - 172.

Codina, R., Fox, R.W., Lockey, R. F., DeMarco, P. and Bagg, A., 2008. Typical levels of airborne fungal spores in houses without obvious moisture problems during a rainy season in Florida, USA. J. Investig Allergol Clin. Immunol., 18(3): 156-162.

Cowan, S.T., 1974. Cowan and Steel's manual for the identification of medical bacteria. Second Edition. Cambridge University Press. 678p

Damicone, J. P., Lynn B. 2013. Common Diseases of Tomatoes - Part II Diseases Caused by Bacteria, Viruses, and Nematodes. Oklahoma Cooperative Extension Service, Division of Agricultural Sciences and Natural Resources -Oklahoma State University.

Domsch, K. H., Gams, W., 1970. Pilze aus Agrarboden. Gustav Fischer, Germany. 571p

Domsch, K.M., Gams, W., Anderson, T., 1993. Compendium of Soil Fungi. Volume 1, Second Edition. Academic Press, London. 860 pp.

Ghosh, A., 2009. Identification of microorganisms responsible for spoilage of tomato (Lycopersicum esculentum) fruit. Journal of Phytology, 1(6): $414-416$.

Hillock, D., 2011 Year of the Tomato. National Garden Bureau [Online] [Available at: http://www.ngb.org/year_of/index.cfm?YOID=16.] [Accessed: 5 - 21 - 2017].

Holt, J.G., Krieg, N.R., Sneath, P.H.A., Staley, J.T., Williams, S.T., 1994. Bergey's Manual of Determinative Bacteriology. Ninth Edition. Williams and Wilkins. 561p.

Kader, A. A., 1983. Physiological and biochemical effects of carbon monoxide added to controlled atmospheres on fruits. Acta Horticulturae, 138: 221-226.

Mbah, C. N., 2006. Influence of organic wastes of plant growth parameters and nutrient uptake by maize (Zea mays L.). Nigeria Journal of Soil Science, 16: $104-108$.

McGriffen, M. E., Pantome, D. J. and Maisuna, J. B., 1994. Path analysis of tomato yield components in relation completion with block and eastern nightshade. Journal of America Society of Horticultural Science, 119: 6-11.

Mukhtar, I. S., Mushtaq, A. A. and Khokhar, I., 2012. Phyllospheric 
microflora of Cuscuta pedicillata Ledeb and its host Trifolium alexandrium L. Sarhad Journal of Agriculture, 28(3):437-441

Mukhtar, I., Mushtaq, S., Ali, A., Khokhar, I., 2010. Epiphytic and endophytic phyllosphere microflora of Cassytha filiformis L. and its hosts. Ecoprint, 17: 1-8

Murali, J. K., Asish, B., Kumar, P. S., 2013. Phytochemical analysis and antimicrobial studies of various extracts of Tomato (Solanium lycopersicum L.). Scholars Academic Journal of Biosciences, 1(2): 34 38.

Naseer, U., Hajera, T., Ali, M. N., Ponia, K., 2012. Evaluation of antibacterial activity of five selected fruits on bacterial wound isolates. International Journal Pharmacy Biological Science, 3(4): 531 - 546.

Ogwu, M. C., Osawaru, M. E., 2014. Comparative Study of Microflora Population on the Phylloplane of Common Okra [Abelmoschus esculentus L. (Moench.)]. Nig J. Biotech., 28: 17-25

Ogwu, M. C., Osawaru, M. E.,2015. Soil characteristics, microbial compostion of plot, leaf count and sprout studies of cocoyam (Colocasia [Schott] and Xanthosoma [Schott], Araceae) Collected in Edo State, Southern Nigeria. Science, Technology and Arts Research Journal, 4(1): 34-44. DOI: $10.4314 /$ star.v4i1.5

Ogwu, M. C., Chime, A.O., Osawaru, M. E., Ogunoye, A. O., 2016b. Microbial evaluation of four accessions of tomato (Solanum lycopersicum [Lin.] Con. Solanaceae). Proceeding of the International Conference on Natural Resource Development and Utilization $4^{\text {th }} \quad$ Edition. $232-244 \mathrm{pp}$

Ogwu, M. C., Osawaru, M. E., Aiwansoba, R. O. and Iroh, R. N. $2016 a$. Status and prospects of vegetables in Africa. Proceedings of NTBA/NSCB Joint Biodiversity Conference; Unilorin 2016. 47 - 57pp

Okoli C. A. N., Erinle I. D. 1990. Comparative rate of rot induction by nine fungal pathogens on stored tomato fruits in Nigeria. Journal of Stored Products Research, 26: 17 - 90.

Onuorah, S., Orji M.U. 2015. Fungi Associated with the Spoilage of Postharvest Tomato Fruits Sold in Major Markets in Awka, Nigeria. Universal Journal of Microbiology Research, 3(2): 11-16, 2015 http://www.hrpub.org DOI: 10.13189/ujmr.2015.030201

Osawaru, M. E., Ogwu, M. C., Ogbeifun, N. S., Chime, A. O. 2013. Microflora diversity on the phyloplane of wild okra (Corchorus olitorius L. Jute). Bayero Journal of Pure and Applied Sciences, 6(2): 136 - 142. http://dx.doi.org/10.4314/bajopas.v6i2.29

Renard, M. G. C. C., Ginies, C., Gouble, B., Bureau, S., Causse, M., 2013. Home conservation strategies for tomato (Solanum lycopersicum): Storage temperature vs. duration - Is there a compromise for better aroma preservation? Food Chemistry, 139: 825 - 836. https://doi.org/10.1016/j.foodchem.2013.01.038

Romero, F.M., Marina, M., Pieckenstain, F.L., 2014. The communities of tomato (Solanum lycopersicum L.) leaf endophytic bacteria, analyzed by 16S-ribosomal RNA gene pyrosequencing. FEMS Microbiol. Lett., 351: 187-194. DOI: 10.1111/1574-6968.12377

Salunkhe, D. K. and Norton, R. A. 1960. Prepackaging treatments extend storage life of fruit. Utah Agricultural Experiment Station for Farm and Home Science Bull. 21p.

Simonne, A.H., Behe, B.K., Marshall, M.M., 2006. Consumers prefer lowpriced and high-lycopene-content fresh-market tomatoes. HortTechnology, 16(4): 674-681.

Singh, B., Littlefield, N.A., Salunkhe, D. K. 1970. Effect of CA storage on amino acids, sugar, and rate of respiration of Lambert sweet cherry fruit. Journal of America Society for Horticultural Science, 95: 458 461.

Tahir, I.I., Johansson, E., Olsson, M.E., 2009. Improvement of apple quality and storability by a combination of heat treatment and controlled atmosphere storage. HortScience, 44: 1648-1654

Toor, R.K., Savage, G.P., 2006. Changes in major antioxidant components of tomatoes during post-harvest storage. Food Chemistry, 99: 724-727.

Wogu, M. D., Ofuase, O., 2014. Microorganisms responsible for the spoilage of tomato fruits, Lycopersicum esculentum, sold in markets in Benin City, Southern Nigeria. School Academic Journal of Biological science, 2(7): 459 - 466 